\title{
Picture Quiz: A 22 year old man with acute genital oedema and a swollen ankle
}

Danielle J C Komen and colleagues, the authors of this Endgames quiz (BMJ 2011;343:d3132, doi:10.1136/bmj.d3132), have alerted us to their omission relating to the European Medicines Agency's recent approval of $\mathrm{C} 1$ esterase inhibitor $(\mathrm{C} 1 \mathrm{INH})$ produced by transgenic rabbits. They state that because of the small, but serious, risk of viral transmission using human plasma or plasma derived products, human recombinant $\mathrm{C} 1 \mathrm{INH}$ produced by transgenic animals has been developed and was approved by the European Medicines Agency in October 2010.

Cite this as: $B M J 2011 ; 343: d 4873$ 